\title{
AUDITING OF COMPANY FINANCIAL STANDING USING AGGREGATE MEASURE
}

\section{Robert Kowalak}

Wroclaw University of Economics and Business, Wroclaw, Poland

e-mail: robert.kowalak@ue.wroc.p1

ORCID: 0000-0001-5395-9395

\section{(C) 2020 Robert Kowalak}

This is an open access article distributed under the Creative Commons Attribution-NonCommercial-NoDerivs license (http://creativecommons.org/licenses/by-nc-nd/3.0/)

DOI: 10.15611/fins.2020.1.02

JEL Classification: G33, G34, M41, M42

\begin{abstract}
A model of evaluation of company financial standing is presented in the article, based on the concept of aggregate synthetic measure. By calculating threshold values for the aggregate measure, statutory auditors gain a valuable tool to help determine the potential breach of company financial sustainability as well as evaluate company financial standing relative to other reporting periods. The main purpose of the author was to present a new conception of analysis company financial standing based on matrix measure. Theoretical and empirical methods are used in the paper. The theoretical part describes own model based on matrix measure. The empirical part shows the use of the model to analyze the financial condition of a stock exchange enterprise. Research methods concentrated on data and information collected from one company (case study), induction, deduction and literature analysis.
\end{abstract}

Keywords: financial analysis, aggregate measure, financial ratios.

\section{Introduction}

An evaluation of company financial standing performed by a statutory auditor is an important element of company financial audit report. Based on audit results, the company may be evaluated in terms of its financial performance and continuity of operation, as well as provide early warning against potential bankruptcy. Typically, the auditing process involves the analysis of financial reports and selected indicators, supplemented by analyses based on discriminant models.

This paper postulates an improved model of financial evaluation using an aggregate measure based on the multidimensional evaluation of key financial performance indicators used in statutory auditing process. The most important advantage of the postulated method is the ease of evaluation. In addition, by combining fragmentary financial indicators used for the evaluation of individual areas of company performance, the aggregate measure provides an accurate 
evaluation of company standing. By supplementing the postulated model with data gathered in companies with declared bankruptcy, a critical value of the aggregate measure may be established, to serve as threshold signifying high risk of financial instability of economic entities under evaluation.

The principal objective of the postulated model is to evaluate the future trend of company financial standing (improvement vs. decline) using economic information collated over several reporting periods. The postulated model may also be employed for the purpose of comparing company performance against other economic entities to evaluate its financial standing over a given period relative to other economic actors. The model may be construed based on the assumption that key indicators equally influence the synthetic measure, but it also allows for employing weighs for individual indicators to reflect their varying impact upon the aggregate measure.

\section{Construction of the aggregate measure for company financial evaluation}

Construction of the aggregate measure model to be used for the purpose of evaluating company financial standing typically involves four stages: ${ }^{1}$

1. Selection of information sources and evaluation criteria.

2. Selection of financial indicators for each evaluation criterion.

3. Normalization of indicators.

4. Designing the aggregate measure.

In the case of company financial evaluation, the information to be used is typically taken directly from company financial reports or derived from financial indicators built on the basis of such reports. In the case of companies listed on Warsaw Stock Exchange, the above criteria may be supplemented by additional information, such as the number of company shares in circulation. The most fundamental measures derived from company financial reports include:

- total assets to illustrate the scale of company current operation,

- net financial result, as a measure of company effectiveness in utilizing its assets.

If we choose to employ financial indicators as a basis for the construction of the model, selection should be limited to just the most fundamental ones - those that best represent the individual criteria of evaluation, such as (without limitation) liquidity, profitability, debt, activity and turnover. In addition, the model may be supplemented by market ratios. The selection of indicators describing all areas of company activities allows for the objectivity of the calculated measure. Most of the financial ratios which could be used in the model are presented in (e.g. Bragg, 2006, 2010; Bull, 2008; Tyran, 1986, 2001; Walsh, 2006; Rist and Pizzica, 2015; Kowalak, 2008; Wędzki, 2019). P. Figura presents the benchmark financial ratios for stock exchange enterprises (Figura, 2012).

${ }^{1}$ M. Marcinkowska (2007, p. 586) postulates 3 stages of the process: selection of evaluation criteria and individual measures, bringing the measures to comparable values, construction of the aggregate measure. 
R. Kowalak presents the following criteria (Kowalak, 2008):

- liquidity ratios,

- turnover ratios,

- debt ratios,

- efficiency ratios,

- profitability ratios,

- market ratios.

T. Korol, for his model, distinguishes the following group of financial ratios (Korol, 2013):

- liquidity ratios,

- profitability ratios,

- debt ratios,

- efficiency ratios.

S. Bragg divides indicators into twelve criteria (Bragg, 2006):

- asset utilization measures,

- operating performance measures,

- cash flow measures,

- liquidity measures,

- capital structure and solvency measures,

- return on investment measures,

- market performance measures,

- measures for the Accounting and Finance Department,

- measures for Engineering Department,

- measures for the Logistics Department,

- measures for the Production Department,

- measures for the Sales and Marketing Department.

For the purpose of the model, indicators are divided into stimulants and destimulants.

It is highly advisable to employ this classification in the process of selecting the indicators. Certain problems may be found in the case of nominants. These typically include liquidity ratios, as one of the fundamental elements of financial evaluation of companies. After selecting suitable indicators, a matrix of features (indicators) is construed for individual periods of evaluation, as presented in Table 1.

Table 1. Matrix of indicators per reporting period

\begin{tabular}{|l|c|c|c|c|}
\hline Measure & Year 1 & Year 2 & $\ldots$ & Year $n$ \\
\hline Measure 1 & $\mathrm{x}_{11}$ & $\mathrm{x}_{12}$ & & \\
\hline Measure 2 & $\mathrm{x}_{21}$ & $\mathrm{x}_{22}$ & & \\
\hline$\ldots$ & $\ldots \ldots$ & $\ldots \ldots$ & $\ldots \ldots$ & $\ldots$ \\
\hline Measure $m$ & $\mathrm{x}_{m 1}$ & & & $\mathrm{x}_{m n}$ \\
\hline
\end{tabular}

Source: own research. 
Normalization of indicators for the purpose of the postulated mode involves calculating the maximum values for stimulant ratios and minimum values for destimulant ratios. The normalized values $z_{i j}$ are calculated using the following formulas (Nowak, 1990, p. 89):

stimulants

$$
z_{i j}=\frac{x_{i j}}{\max \left\{x_{i j}\right\}},
$$

where: $x_{i j}$ - value of $i$ measure in year $j$,

$\max \left\{x_{i j}\right\}$ - maximum value of $i$ measure in year $j$,

destimulants

$$
z_{i j}=\frac{\min \left\{x_{i j}\right\}}{x_{i j}},
$$

where: $\min \left\{x_{i j}\right\}-$ minimal value of $i$ measure in year $j$.

The aggregate measure is calculated based on either of the following assumptions (Kowalak, 2008):

- all indicators have the same impact on the measure value,

- indicators have varied impact on the measure value, which requires evaluation of respective weighs (coefficients).

In the case of equal impact of indicators upon the value of the aggregate measure, the calculation employs the following formula:

$$
z_{j}=\frac{1}{m} \sum_{i=1}^{m} z_{i j}
$$

where: $z_{j}$ - aggregate measure for year $j$,

$m$ - number of indicators employed in the model.

In the case of models based on a hierarchy of indicators, the above formula incorporates their respective weighs represented here by $g_{i}$.

$$
z_{j}=\sum_{i=1}^{m} g_{i} z_{i j},
$$

where: $g_{i}-$ weigh attributed to $i$ indicator.

The values of $g_{i}$ must fall in the range of 0 to 1 . The sum of weighs must equal 1. Measures considered high impact should be attributed higher weighs (Nowak, 1995, p. 119).

The most favorable financial standing is associated with the highest value of the aggregate measure, ideally close to 1 . Graphic presentation of that model could be found in (Kowalak, 2008; Hutton and Zairi, 1995). R. Kowalak presented the use of that graphic model for the financial analysis. R. Hutton and M. Zairi presented how to use the matrix measure for the benchmarking purposes. 


\section{An example of company financial standing evaluation}

Is the exemplary analysis based on financial reports of "Beer" S.A. ${ }^{2}$ company for the period of 2014-2017? To evaluate the financial standing of the company under study (for the audit purposes), the following key financial indicators are used ${ }^{3}$ :

- total assets,

- net financial result,

- return on assets,

- return on equity,

- net profit margin,

- return on sales,

- liquidity ratio I,

- liquidity ratio II,

- liquidity ratio III,

- payment turnover ratio,

- accrued liability expenses,

- inventory turnover,

- equity to fixed assets ratio,

- financing sustainability ratio.

The values of key financial indicators of "Beer" S.A. are presented in Table 2.

Table 2. Key financial indicators of "Beer" S.A. in the years 2014-2017

\begin{tabular}{|l|r|r|r|r|}
\hline \multicolumn{1}{|c|}{ Indicator } & \multicolumn{1}{c|}{2014} & \multicolumn{1}{c|}{2015} & \multicolumn{1}{c|}{2016} & \multicolumn{1}{c|}{2017} \\
\hline Total assets (in thousand PLN) & 2.216077 & 2.435 .367 & 2.504 .815 & 2.554 .536 \\
\hline Net financial result (in thousand PLN) & 322.411 & 392.046 & 453.710 & 349.736 \\
\hline Return on assets (\%) & 14,55 & 16,10 & 18,11 & 13,69 \\
\hline Return on equity (\%) & 35,26 & 51,25 & 61,23 & 49,95 \\
\hline Net profit margin (\%) & 14,47 & 15,79 & 11,77 & 9,23 \\
\hline Return on sales (\%) & 17,17 & 19,03 & 14,59 & 9,38 \\
\hline Liquidity ratio I & 0.57 & 0.57 & 1.03 & 0.75 \\
\hline Liquidity ratio II & 0.49 & 0.44 & 0.80 & 0.61 \\
\hline Liquidity ratio III & 0.00 & 0.02 & 0.05 & 0.01 \\
\hline Payment turnover ratio & 63.85 & 88.35 & 70.77 & 91.62 \\
\hline Accrued liability expenses & 158.48 & 262.06 & 110.46 & 166.75 \\
\hline Inventory turnover ratio & 13.43 & 34.66 & 25.52 & 22.68 \\
\hline Equity to fixed assets ratio & 0.52 & 0.47 & 0.50 & 0.51 \\
\hline Financing sustainability ratio & 0.64 & 0.41 & 0.60 & 0.39 \\
\hline
\end{tabular}

Source: own research.

2 Name has been changed.

${ }^{3}$ Appendix No. 2 to Standard 2 of the Resolution of the National Chamber of Statutory Auditors. Indicators as described in (Kowalak, 2002, pp. 82-86). 
Based on standard financial evaluation methods, the company under study can be considered profitable over any reporting period of the range, with 2016 profitability being the most pronounced. The company value, as measured by total assets, increased with each consecutive year.

The company financial liquidity ratios should be evaluated as insufficient. Minimum expected values for individual liquidity indicators should amount to:

- for I degree liquidity: 1.2 ,

- for II degree liquidity: 1.0,

- for III degree liquidity: 0.25 .

Neither of the reporting periods shows the expected values. The best relative liquidity ratios were reached in the year 2016.

The profitability of the company under study is high, both in terms of sales, assets and equity ratio values. Similarly to the liquidity values, the highest values of asset and equity profitability ratios were found in the year 2016. The best sales profitability value was reached in the year 2015 , followed by a steady drop of the indicators in the following periods.

Company activity and turnover are represented by the ratios of payment rotation, accrued liabilities and inventory turnover. The average collection period is high (more than two months). The best results are again found in the year 2016. The average payables payment period is very high, oscillating around six months. Here, again, the highest values are associated with the year 2016. Inventory turnover ratios can be considered satisfactory.

The ratios of equity to fixed assets and financing sustainability reach satisfactory values and remain relatively steady over the whole period under study.

For the purpose of aggregate model, the key financial indicators should be divided into stimulants and destimulants.

Stimulants include the following key indicators:

- total assets,

- financial result,

- return on assets,

- return on equity,

- net profit margin,

- return on sales,

- liquidity ratio I,

- liquidity ratio II,

- liquidity ratio III,

- equity to fixed assets ratio,

- financing sustainability ratio.

Destimulants include the following key indicators:

- payment turnover ratio,

- accrued liability expenses,

- inventory turnover. 
The matrix of key indicators after normalization is presented in Table 3.

Table 3. Matrix of normalized key financial indicators of "Beer" S.A. in the years 2014-2017

\begin{tabular}{|l|c|c|c|c|}
\hline \multicolumn{1}{|c|}{ Indicator } & 2014 & 2015 & 2016 & 2017 \\
\hline Total assets & 0.868 & 0.953 & 0.981 & $\mathbf{1 . 0 0 0}$ \\
\hline Net financial result & 0.711 & 0.864 & $\mathbf{1 . 0 0 0}$ & 0.771 \\
\hline Return on assets & 0.803 & 0.889 & $\mathbf{1 . 0 0 0}$ & 0.756 \\
\hline Return on equity & 0.576 & 0.837 & $\mathbf{1 . 0 0 0}$ & 0.816 \\
\hline Net profit margin & 0.916 & $\mathbf{1 . 0 0 0}$ & 0.745 & 0.585 \\
\hline Return on sales & 0.902 & $\mathbf{1 . 0 0 0}$ & 0.767 & 0.493 \\
\hline Liquidity ratio I & 0.553 & 0.553 & $\mathbf{1 . 0 0 0}$ & 0.728 \\
\hline Liquidity ratio II & 0.613 & 0.550 & $\mathbf{1 . 0 0 0}$ & 0.763 \\
\hline Liquidity ratio III & 0.000 & 0.400 & $\mathbf{1 . 0 0 0}$ & 0.200 \\
\hline Payment turnover ratio & $\mathbf{1 . 0 0 0}$ & 0.723 & 0.902 & 0.697 \\
\hline Accrued liability expenses & 0.697 & 0.422 & $\mathbf{1 . 0 0 0}$ & 0.662 \\
\hline Inventory turnover ratio & $\mathbf{1 . 0 0 0}$ & 0.387 & 0.526 & 0.592 \\
\hline Equity to fixed assets ratio & $\mathbf{1 . 0 0 0}$ & 0.904 & 0.962 & 0.981 \\
\hline Financing sustainability ratio & $\mathbf{1 . 0 0 0}$ & 0.641 & 0.938 & 0.609 \\
\hline
\end{tabular}

Source: own research.

Values of the aggregate measure for individual reporting periods are shown in Table 4 and Figure 1. For the purpose of calculation it was assumed that key indicators equally influence the value of the aggregate measure.

Table 4. Aggregate measure of financial standing of "Beer" S.A. in the years 2014-2017

\begin{tabular}{|c|c|c|c|c|}
\hline Year & 2014 & 2015 & 2016 & 2017 \\
\hline Aggregate measure & 0.760 & 0.723 & $\mathbf{0 . 9 1 6}$ & 0.689 \\
\hline
\end{tabular}

Source: own research.

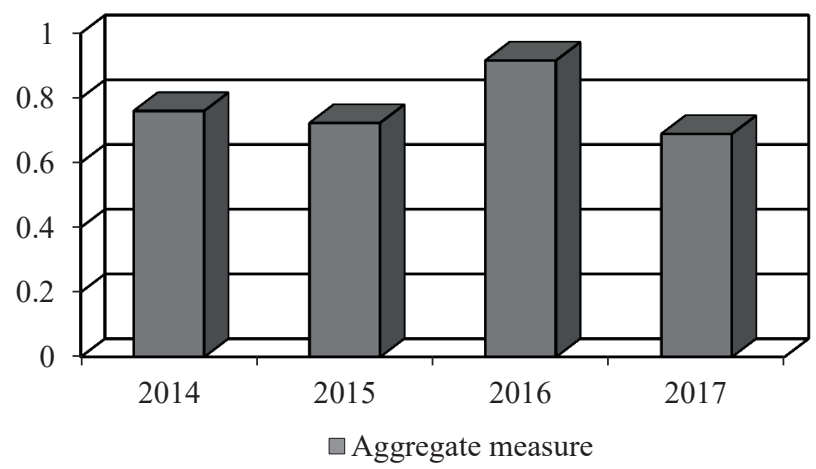

Fig. 1. Aggregate measure of financial standing of "Beer" S.A. in the years 2014-2017

Source: own research. 
As seen in Table 4, the financial standing of the company under study was at its highest in the year 2016, with 2017 values representing the lowest standing. Interestingly, despite the market recession, the company under study displays good financial standing, although with a marked drop in the year 2017.

\section{Conclusions}

The postulated model based on the concept of aggregate measure can be used to complement the traditional analysis using financial indicators as an auditors tool to make an opinion about accounting going-concern principle. The model not only helps monitor the financial standing of companies, but it can also serve as a tool for cross-company comparisons. By studying data collected in companies with declared bankruptcy, it can also be employed to establish threshold values to serve as early indicators of potential insolvency or breach of financial sustainability. In the case of bankruptcy risk, the trend of the aggregate measure will typically be decreasing and approaching zero. The postulated model can also be used to establish which reporting period within a given timeframe yielded best financial results relative to other periods. The example provided herein demonstrates that the actual calculations are not overly complicated, while retaining clarity and legibility of interpretation. As such, it may prove to be a valuable addition in the toolset of statutory auditors, to help pass the opinion on the potential breach of company financial sustainability (accounting going-concern principle).

\section{References}

Bragg, S. (2006). Business Ratios and Formulas. Hoboken: John Wiley \& Sons.

Bragg, S. (2010). Wskaźniki w analizie działalności przedsiębiorstwa. Warszawa: Oficyna Wolters Kluwer business.

Bull, R. (2008). Financial Ratios. How to Use Financial Ratios to Maximise Value and Success for your Business. Burlington: CIMA Publishing.

Figura, P. (2012). Wartości wzorcowe wskaźników finansowych przedsiębiorstw giełdowych. Warszawa: CeDeWu.pl.

Hutton, R., and Zairi, M. (1995). Effective benchmarking through a prioritization methodology. Total Quality Management, 6(4).

Korol, T. (2013). Nowe podejście do analizy wskaźnikowej w przedsiębiorstwie. Warszawa: Oficyna Wolters Kluwer business.

Kowalak, R. (2002). Analiza wskaźnikowa w badaniu sprawozdań finansowych. Prace Naukowe Akademii Ekonomicznej im. Oskara Langego we Wroctawiu, (929).

Kowalak, R. (2008). Ocena kondycji finansowej przedsiębiorstwa w badaniu zagrożenia upadłościa. Gdańsk: ODDK.

Kowalak, R. (2011). Syntetyczny miernik oceny kondycji finansowej przedsiębiorstwa. Rachunkowość w teorii i praktyce. Finanse, Rynki Finansowe, Ubezpieczenia, (41), 607-616.

Marcinkowska, M. (2007). Ocena działalności instytucji finansowych. Warszawa: Difin. 
Nowak, E. (1990). Metody taksonomiczne w klasyfikacji obiektów społeczno-gospodarczych. Warszawa: PWE.

Nowak, E. (1995). Rachunkowość menedżerska. Wrocław: Wydawnictwo Akademii Ekonomicznej im. Oskara Langego we Wrocławiu.

Rist, M., and Pizzica, A. (2015). Financial Ratios for Executives. New York: Apress.

Tyran, M. (1986). Handbook of Business and Financial Ratios. Harlow: Prentice-Hall.

Tyran, M. (2001). Wskaźniki finansowe. Warszawa: Dom Wydawniczy ABC.

Walsh, C. (2006). Key Management Ratios. The Clearest Guide to the Critical Numbers that Drive your Business. Harlow: Prentice-Hall.

Wędzki, D. (2019). Analiza wskaźnikowa sprawozdania finansowego wedlug polskiego prawa bilansowego. Warszawa: Wydawnictwo Nieoczywiste.

\section{OCENA KONDYCJI FINANSOWEJ PRZEDSIĘBIORSTWA Z WYKORZYSTANIEM SYNTETYCZNEGO MIERNIKA}

Streszczenie: Artykuł jest poświęcony modelowi oceny kondycji finansowej przedsiębiorstwa z zastosowaniem zagregowanego wskaźnika syntetycznego. Wyznaczając wartości krytyczne wskaźnika, można ocenić, czy badane przedsiębiorstwo jest zagrożone niewypłacalnością, czy też nie oraz czy kondycja finansowa jest lepsza lub gorsza w badanym okresie. Głównym celem autora było opracowanie nowej koncepcji oceny kondycji finansowej przedsiębiorstwa, bazującej na macierzy mierników. Artykuł składa się z części teoretycznej i empirycznej. W części teoretycznej opisano własny model, bazujący na macierzy mierników. W części empirycznej przedstawiono wykorzystanie modelu w ocenie kondycji finansowej jednej ze spółek akcyjnych. W artykule wykorzystano następujące metody badawcze: analizę piśmiennictwa, indukcję, dedukcję i studium przypadku.

Słowa kluczowe: analiza finansowa, miernik zagregowany. 